\title{
Exploring Students' Self-Regulated Learning in Vocational Education and Training
}

Citation for published version (APA):

Jossberger, H., Brand-Gruwel, S., van de Wiel, M. W. J., \& Boshuizen, H. P. A. (2020). Exploring

Students' Self-Regulated Learning in Vocational Education and Training. Vocations and Learning, 13(1), 131-158. https://doi.org/10.1007/s12186-019-09232-1

Document status and date:

Published: 01/04/2020

DOI:

10.1007/s12186-019-09232-1

Document Version:

Publisher's PDF, also known as Version of record

Document license:

Taverne

\section{Please check the document version of this publication:}

- A submitted manuscript is the version of the article upon submission and before peer-review. There can be important differences between the submitted version and the official published version of record.

People interested in the research are advised to contact the author for the final version of the publication, or visit the DOI to the publisher's website.

- The final author version and the galley proof are versions of the publication after peer review.

- The final published version features the final layout of the paper including the volume, issue and page numbers.

Link to publication

\footnotetext{
General rights rights.

- You may freely distribute the URL identifying the publication in the public portal. please follow below link for the End User Agreement:

www.umlib.nl/taverne-license

Take down policy

If you believe that this document breaches copyright please contact us at:

repository@maastrichtuniversity.nl

providing details and we will investigate your claim.
}

Copyright and moral rights for the publications made accessible in the public portal are retained by the authors and/or other copyright owners and it is a condition of accessing publications that users recognise and abide by the legal requirements associated with these

- Users may download and print one copy of any publication from the public portal for the purpose of private study or research.

- You may not further distribute the material or use it for any profit-making activity or commercial gain

If the publication is distributed under the terms of Article $25 \mathrm{fa}$ of the Dutch Copyright Act, indicated by the "Taverne" license above, 


\title{
Exploring Students' Self-Regulated Learning in Vocational Education and Training
}

\author{
Helen Jossberger ${ }^{1}$ (D) Saskia Brand-Gruwel ${ }^{2,3}$ - Margje W. J. van de Wiel ${ }^{4}$. \\ Henny P. A. Boshuizen ${ }^{2,5}$
}

Received: 20 December 2018 / Accepted: 2 September 2019 /Published online: 23 October 2019

(C) Springer Nature B.V. 2019

\begin{abstract}
The aim of the present empirical study was to explore students' self-regulated learning behaviours in vocational education and training and to describe the micro processes associated with planning, monitoring and evaluating during practical learning tasks. The 18 participants were well-performing students from upper secondary vocational education. We collected data from observations, interviews and self-reports to gain detailed insights into students' behaviours and thoughts during practical task performance. The results reveal that most of the students planned their time and resources, but did not develop elaborate plans to regulate their learning behaviours. They monitored their work carefully and adjusted when necessary. When evaluating, students focussed more on work outcomes than learning processes. The results also showed that the students' actual behaviours corresponded with self-reports on internal regulation, with three students overestimating their internal regulation. This study sheds light on an underexplored context and population regarding self-regulated learning. Though the well-performing vocational students engaged in self-regulation, their selfregulating behaviours were led by a combination of hands-on activities and evolving work outcomes. Thus, it was the emerging performance and experiences that triggered their learning. Although self-regulated learning behaviours in vocational education and training were present, we conclude that instructional support needs to be developed and empirically tested to actively facilitate and foster vocational students' learning by doing and reflection.
\end{abstract}

Keywords Self-regulated learning · Vocational education and training · Qualitative research

Helen Jossberger

helen.jossberger@ur.de

Extended author information available on the last page of the article 


\section{Introduction}

Research in academic settings has shown that self-regulated learning (SRL) is associated with learning success (e.g., Dignath and Büttner 2008; Müller and Seufert 2018; Panadero et al. 2017; Zimmerman 2013). SRL is also considered important in workplace learning, as professionals must manage their own learning for work (e.g., Littlejohn et al. 2016; Sitzmann and Ely 2011; Tynjälä 2008; van de Wiel et al. 2011). Despite these findings, empirical research on SRL in vocational education and training (VET) is scarce. Still, little is reported about vocational students regulating their learning (Jossberger et al. 2015, 2018; Khaled et al. 2016), although selfregulation of cognitive and affective processes during practical task performance in learning for the professions is critical for helping students effectively learn and master independence in VET (Boekaerts and Cascallar 2006; De Bruijn and Leeman 2011; Jossberger et al. 2010; Van Grinsven and Tillema 2006).

The aim of the present qualitative study was to gain a better understanding of what vocational students actually do in practice and what SRL they apply in VET. These insights will shed light on the interplay between self-regulating learning and performance to help identify ways to improve VET students' learning from practice.

We provide a brief theoretical overview of self-regulated learning - mostly based on research in academic settings - and relate these findings to the context of VET. This outline leads to the research question of this study. Then, we present our qualitative case study to enrich understandings of vocational students' SRL behaviours. Wellperforming VET students were selected supposing that, if these students exhibit SRL, it is likely to occur in the focal population. Finally, the results are discussed, and practical implications are proposed.

\section{Self-Regulated Learning during Task Performance}

Learners differ in their task approaches, and skilful learners have been shown to direct regulatory processes to the task, the self, and the context (e.g., Schunk et al. 2018).

Zimmerman (2005) defined self-regulation as: 'self-generated thoughts, feelings, and actions that are planned and cyclically adapted to the attainment of personal goals' (p. 14; also in Schunk et al. 2018). Student motivation is both a starting point and an outcome of self-regulation processes. As early as the 1990s, Zimmerman et al. 1992, Zimmerman and Bandura 1994 found that self-efficacy for SRL correlated with selfefficacy for academic achievement, which, in turn, predicted students' grade goals and final grades. Self- regulated learners exhibit a high sense of efficacy. Consequently, they set more challenging knowledge and skill goals for themselves and display greater persistence and effort to achieve them (see also Zimmerman 2013). Similarly, Pintrich (1999) found that skilful learners reported significantly greater intrinsic interest and exhibited greater self-efficacy than less skilful learners. According to Müller and Seufert (2018), while many studies have confirmed the positive effects of selfefficacy on SRL, self-efficacy is also a consequence of SRL. Skilful SRL students who are agents of their own learning and professional development are able to use motivational strategies purposefully and to persist in situations of motivational threats (Boekaerts and Cascallar 2006; Smit et al. 2017). 
We distinguish three cyclically interrelated phases of task performance: preparation, execution and completion (cf. Zimmerman 2005). During these phases, various processes and activities take place, and students make different decisions to organise their performance and learning. Feedback loops regulate covert, behavioural and environmental processes and guide adaptations during the learning task (Zimmerman 2013). The better activities are executed in one phase, the better and smoother are activities in the next phase. Zimmerman $(2005,2006)$ found that this is exactly what self-regulated learners do: they orient, plan, monitor, adjust, evaluate and reflect.

When preparing, self-regulated learners begin by orienting towards practical learning tasks and planning the steps necessary to accomplish the task. They set specific goals that focus on learning and organise information and resources. Moreover, they initiate efforts to select or arrange their physical settings according to their own preferences for working and learning (e.g., preventing distraction).

During task execution, self-regulated learners monitor what they are doing by checking their plans and keeping in mind future steps. Monitoring helps them detect mistakes or deviations from the plan, allowing them to adjust, adapt, fine-tune or abandon strategies and identify, retrieve, and seek new information (Winne 2018; Zimmerman 2013). By monitoring their progress, students also determine when, where, and how to find help or necessary information (Newman 2002; Zimmerman 2006; Zimmerman and Martinez-Pons 1986). Thus, learning is often highly interactive. As Järvenoja et al. (2015) stated: 'learning does not happen in a vacuum but takes place in constantly changing contexts and is re-formed every time' (p. 204). Learning occurs when iterating between planning and monitoring during task performance by experimenting and consulting available resources.

In the completion phase, self-regulated learners seek opportunities to assess and evaluate their task performance by gathering information about their outcome, level of understanding, effort and use of strategies (Zimmerman 2013). They attribute negative outcomes to ineffective strategies and subsequently strive for more adaptive strategy without doubting their capabilities. By reflecting on their progress and considering their causal attributions and the opinions of others, learners can discover how they have improved in relation to their goals and expectations and use their actual experience to improve performance in future tasks (Ertmer and Newby 1996; Hattie and Timperley 2007; Zimmerman 2013). Reflecting on their professional development is also necessary to identify those aspects that need further improvement. By setting clear goals, students can practice deliberately to eliminate weaknesses in their performance (Ericsson 2018).

\section{Self-Regulated Learning in Vocational Education and Training}

When comparing VET students with academic education students, conflicts between hand versus mind, brawn versus brain and manual versus mental education seem to persist. Students in VET are seen as 'less able, more disruptive and less interested in schooling compared to students in technical and general education streams' (Stevens and Vermeersch 2010, p. 279). Cognitive ability gaps and VET students' lower socioeconomic status have been consistently reported (Choi et al. 2019). Moreover, 22,948 students left school without a basic qualification in the Netherlands; in upper 
secondary VET, 4.6 per cent dropped out (Ministry of Education, Culture and Science 2017). In a Europe-wide study, results revealed that dropout rates were higher in countries with less developed VET (Cedefop 2016).

As VET is supposed to equip and empower young people with the knowledge and skills needed to learn and work autonomously to become employed in today's dynamically changing world (De Bruijn et al. 2017; Persico et al. 2015), SRL in VET is crucial for students to learn actively from practical task experiences. Becoming a professional secures and sustains employability across lengthening working lives; therefore, developing skilful professionals is an essential societal goal (Billett et al. 2018). VET strives to foster independent and self-directed learners, and SRL is a promising skill to accomplish this aim (De Bruijn and Leeman 2011; Jossberger et al. 2010).

Clearly, academic and vocational settings in education differ. In contrast to academic settings, which focus on the acquisition of cognitive knowledge and skills, vocational students acquire more domain-specific skills in real-life practical tasks. VET students must work independently, construct meaning, and process information during tangible events and situations using resources, equipment and tools. They must learn during and from their work experience. Here, process and product (outcome) are central elements. Accordingly, students must be aware of their learning processes and choose an appropriate learning path by focusing on performance aspects that need improvement (Jossberger et al. 2010; Kicken et al. 2008; Ericsson 2018). Orienting, planning, monitoring, adjusting, evaluating and reflecting play essential role in learning and performing well within diverse occupational domains of VET. Imagine the following example of a cook in training who must prepare a main dish or even a more complex three-course menu:

During preparation, orienting happens through reading and understanding the recipe and results in the selection and preparation of equipment and food. The cook might have to share equipment and space with other cooks, which requires further arrangements and consultations. Carefully planning the different steps involved is necessary, so that everything is done in time and nothing is cold or over-/undercooked. Setting specific goals helps to cope with the available resources, and limited time. While cooking, monitoring is relevant to prevent mistakes like boiling over or burning by making adjustments (e.g., changing the temperature of the oven). The cook must also evaluate the dish by tasting it, which might lead to further adjustments (e.g., adding seasoning). By reflecting on product and process, the cook becomes aware of aspects that need further improvement during and in future.

This example illustrates that learning in VET is deeply intertwined with and mediated by the practical learning task and interactions with other people. Commonalities across occupational domains are likely. VET students must learn to read and assess a situation, decide what, if any, action to take and monitor themselves (Eraut 2004). For each practical task performance, demands are made and mistakes can happen that should not be covered up. What differs is the nature of the task and the time available. Some practical tasks are time- 
dependent and cannot be stopped immediately as they have already been set in motion (e.g., cooking eggs, soldering on a printed circuit board or jumping with a horse), while other tasks can be interrupted at any moment. Receiving personal, behavioural and environmental feedback enables self-regulated learners to adapt to changes. Being aware of one's performance through selfobservation and careful monitoring facilitates strategic adaptation of one's behaviour to adjust to changing environmental conditions or to control specific feelings or thoughts (Zimmerman 2013).

\section{Aim and Research Question}

The description of SRL generates the contours of the 'ideal' learner: an ideal that is also desirable and strived for in VET. However, as research on SRL has primarily focussed on academic performance, little is known about vocational students' learning and their strategy use in real time. Learning by doing may alter SRL behaviours, as students may be more focussed on performance than on learning. Moreover, the long tradition of privileging cognitions and perceptions as indicators for self-regulation (such as in survey methods used to assess students' self-reports of actions generalised across settings and situations) has failed to provide a detailed characterisation of SRL. The drawback of these 'off-line' (Veenman 2011) methods in the assessment of strategy use is that they reflect not what learners do, but, rather, what they recall or believe they do. Hence, many researchers have stressed the importance of more in-depth and on-line investigations of actions and behaviours (e.g., Ainley and Patrick 2006; Dinsmore et al. 2008; Sitzmann and Ely 2011; Schunk 2008; Veenman 2011; Veenman et al. 2006). This marks a shift in the conceptualisation and measurement of SRL, focusing more on capturing processes and understanding SRL as an event during a learning task (Panadero et al. 2016).

The aim of the present study was to explore SRL behaviours in VET and describe the micro processes associated with planning, monitoring, and evaluating. We addressed the following research question: How do well-performing vocational students self-regulate their learning during practical task performance, and how do they prepare themselves beyond VET for their future vocations? We used a qualitative approach to study SRL in VET by combining observations, interviews and self-reports to reveal what learners actually do and think and how they interact with peers, teachers and equipment. We examined in detail whether and in what ways these vocational students self-regulate their practical task performances and learning.

\section{Method}

\section{Participants}

The participants included 18 students ( 9 females, 9 males) in the first year of upper secondary VET from the Agriculture, Engineering \& Technology and Care \& Welfare 
Table 1 Overview of educational programmes

\begin{tabular}{|c|c|c|}
\hline $\mathrm{N}$ & Educational Programme & Performed task \\
\hline 5 & $\begin{array}{l}\text { Electro-technology } \\
\quad(\mathrm{IV}, \mathrm{RD}, \mathrm{BB}, \mathrm{DE}, \mathrm{RJ})\end{array}$ & $\begin{array}{l}\text { Designing electrical circuits, measuring electricity, soldering on a printed } \\
\text { circuit board, programming an electrical circuit }\end{array}$ \\
\hline 2 & $\begin{array}{l}\text { Automotive engineering } \\
\qquad(\mathrm{NZ}, \mathrm{KT})\end{array}$ & Performing a cylinder leakage test, testing compression and the thermostat \\
\hline 1 & $\begin{array}{l}\text { Aeroplane maintenance } \\
\text { technology }(\mathrm{JB})\end{array}$ & $\begin{array}{l}\text { Machining of aluminium sheet metal based on a drawing (e.g., drilling } \\
\text { holes and slots) }\end{array}$ \\
\hline 1 & Carpentry (GA) & Making a table \\
\hline 1 & Goldsmithery (DS) & Designing and making a silver pillbox \\
\hline 1 & Laboratory technology $(\mathrm{CH})$ & $\begin{array}{l}\text { Measuring the volume of a chemical liquid with a burette, calibrating a } \mathrm{pH} \\
\text { meter, measuring the } \mathrm{pH} \text { of a chemical liquid }\end{array}$ \\
\hline 2 & $\begin{array}{l}\text { Pharmacy assistance } \\
\text { (AD, DH) }\end{array}$ & Filling capsules, making ointments \\
\hline 2 & Medical reception $(\mathrm{CO}, \mathrm{NB})$ & $\begin{array}{l}\text { Measuring blood pressure, cleaning ears, performing an audiometry to } \\
\text { check hearing, applying different kinds of bandages }\end{array}$ \\
\hline 1 & Equine Management $(\mathrm{AB})$ & $\begin{array}{l}\text { Grooming the horse, applying bandages to the legs of the horse to prepare } \\
\text { for transportation, and practicing horseback riding }\end{array}$ \\
\hline 1 & Cooking $(\mathrm{FH})$ & Preparing a main dish and dessert \\
\hline 1 & Hairdressing (RK) & Performing a permanent wave and blow-drying the hairstyle \\
\hline
\end{tabular}

The two-letter abbreviations are unique codes representing each student

sectors. Their mean age was 16.5 years $(S D$ 0.86). Table 1 depicts the participants' educational programmes.

These three sectors were chosen to maximise diversity across professional domains. The sectors address different practical tasks and contexts; however, in each of them, students work on practical tasks related to their future professions. Agriculture incorporates learning tasks related to both Engineering \& Technology and Care \& Welfare, but also includes unique tasks like caring for animals. Strikingly, the sector Engineering \& Technology has predominantly male students; Care \& Welfare has mainly female students. Agriculture is rather mixed with both genders.

To study SRL in action across domains, we selected students known for their learning skills and motivation to investigate when and how they self-regulate during practical task performance and how they learn from these activities. We expected that these students do not procrastinate and are likely to engage in SRL. The sample was chosen as follows. First, teachers from four different pre-vocational secondary vocational schools who had taught the students for two years rated all students in their exam classes on marks and characteristics of skilful learners, including self-regulation, deliberate practice and motivation (Jossberger et al. 2010; see Table 2). Second, the top-rated students were invited to participate. Third, the teachers from upper secondary VET were asked whether they agreed with their pre-vocational secondary school colleagues' appraisals of the students. The teachers indicated that all these students fulfilled the criteria, giving us confidence that these students would show behaviours that would allow us to study and chart the micro processes and practices of SRL. 
Table 2 Selection criteria for students

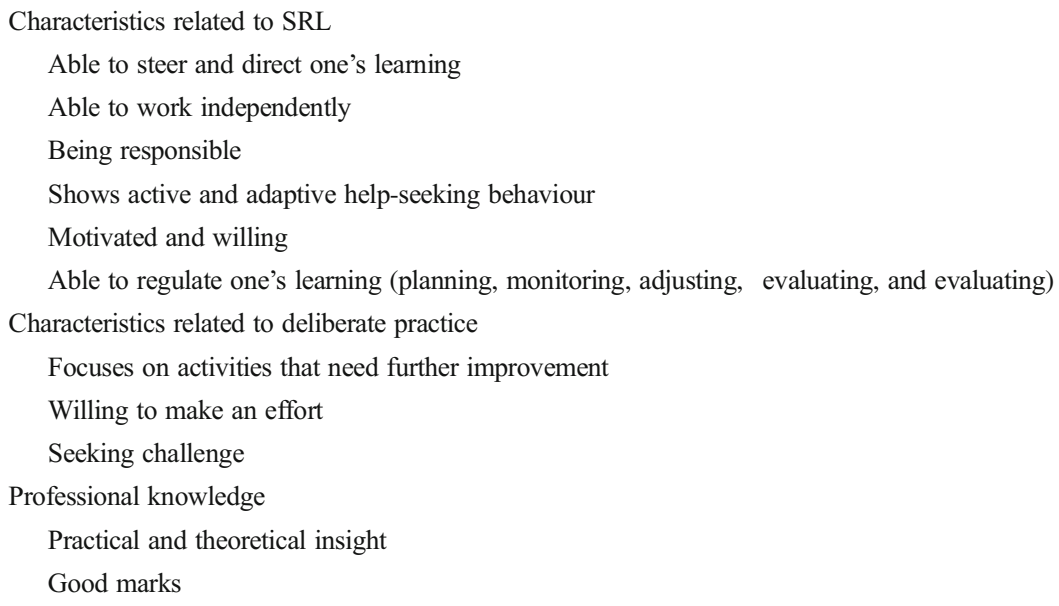

\section{Instruments}

Observations during Practice Each student was observed during a practical lesson using an observation form to record emergent actions and interactions (e.g., hammering, whispering). The observer was positioned close to the student so as to see everything clearly, but kept a safe distance to prevent the observation from being disruptive. Critical incidents indicating self-regulated learning behaviours (e.g., taking notes, looking up information and interacting with peers or the teacher) were noted and used as inputs for the interview.

Audio Recordings during Practice During the observed practical lessons, students' interactions with peers and teachers were captured using a digital voice recorder. The voice recorder hung around the students' necks.

Interview after Practical Lesson A semi-structured and retrospective interview was linked to the observation to illuminate students' actions and interactions and to further explore their lines of thought and the processes behind their actions. The interview scheme consisted of three parts. In the first part, students' observed task performances were discussed based on the observational notes, using critical incidents as cues for the students to recall their thoughts and explain their behaviours. The second part of the interview dealt with students' approaches to tasks in general: their ways of problemsolving, help-seeking behaviours and their ways of evaluating performance. The third part raised questions about students' motivation concerning their education and future professional goals. The questions in the second and third parts of the interview were the same for each student, while part one depended on the tasks students performed during the observations. All interviews were recorded.

Self-Report Questionnaire To investigate how students think about themselves as learners, the Inventory Learning Styles for Secondary Vocational Education (ILS- 
SVE; Slaats and Roosendaal 1996; Slaats et al. 1999) was used. Based on the work of Vermunt (1996), the ILS-SVE was specifically developed for students in upper secondary VET and consists of grammatically easy and comprehensible statements.

The questionnaire included the following four topics: 1) processing strategies, 2) regulation strategies, 3) learning conceptions and 4) motivational orientations. Processing strategies refer to such cognitive learning activities as relating, structuring and memorising content. Regulation strategies deal with coordinating and controlling the learning process through, for example, planning, monitoring and adjusting the study approach. Conceptions of learning refer to students' views and beliefs about the nature and progress of knowledge and learning. Motivational orientations concern students' educational goals (Slaats et al. 1999). In their study, Slaats et al. (1999) developed eight clearly distinguishable scales, with each topic consisting of two scales: 1a) deep processing (e.g., 'When I am dealing with theory, I think of examples in practice'); 1b) shallow processing (e.g., 'I learn definitions by heart'); 2a) internal regulation (e.g., 'I check myself whether I have performed a task correctly'); 2b) external regulation (e.g., 'To know whether I have performed a task correctly, someone else needs to look at it'); 3a) learning as knowledge building (e.g., 'Learning is linking concepts and understanding matters'); 3b) learning as the intake of information ('Learning is to remember the subject matter precisely'); 4a) intrinsic motivation (e.g., 'I follow the educational track because I like it'); and 4b) extrinsic motivation (e.g., 'I learn because it increases my chances on the labour market').

Responses were given on a 5-point Likert scale ranging from 'This never applies to me' to 'This always applies to me' or 'I totally disagree' to 'I totally agree'. All scales exhibited reasonable to good reliability, ranging from .61 to .90 (see Table 5). Similar values of .68 to .90 were reported by Slaats et al. (1999).

\section{Procedure}

Students filled in the ILS-SVE during their summer breaks. From February to April, each student was observed individually, and audio-recordings of their interactions with peers and teachers were made during one practical lesson. We made individual arrangements with each student and the responsible teacher. When selecting a practical lesson, we ensured that the lesson represented a usual lesson focussing on practical task performance. As we observed students only once, we verified whether the observed lesson was representative by asking each teacher and student what was special or different during the observed lesson in comparison to other lessons. Directly after the lesson, the first author interviewed the students in a meeting room at school. Depending on the educational track and the class schedule, observations took, on average, two hours and 58 minutes ( $S D$ 67.39 $\mathrm{min}$ ), and interviewing took $58 \mathrm{~min}(S D 8.37 \mathrm{~min})$. The recordings of the interactions and the interviews were transcribed verbatim.

\section{Analysis}

The data for each student consisted of the observation form, the audio recordings of the interactions, the semi-structured interview and the self-report questionnaire. The 
Table 3 Analysis scheme of SRL

\begin{tabular}{|c|c|}
\hline Categories & Definitions \\
\hline \multicolumn{2}{|l|}{ SRL processes } \\
\hline Orienting & $\begin{array}{l}\text { Statements indicating student-initiated orientation on the task, e.g., "I started } \\
\text { by checking where I stopped last time." }\end{array}$ \\
\hline Planning & $\begin{array}{l}\text { Statements indicating student task-related planning activities, e.g., goal setting, } \\
\text { sequencing, and timing. }\end{array}$ \\
\hline Monitoring & $\begin{array}{l}\text { Statements indicating student-initiated efforts to keep a close eye on their task } \\
\text { performance and checking process and progress. }\end{array}$ \\
\hline Adjusting & $\begin{array}{l}\text { Statements indicating a change in the approach, e.g., correcting a mistake or } \\
\text { using different materials. }\end{array}$ \\
\hline Evaluating & $\begin{array}{l}\text { Statements indicating student-initiated evaluations of the quality of their task } \\
\text { performance with regard to the product, e.g., "Then I take a step back and } \\
\text { look at my performance." }\end{array}$ \\
\hline Reflecting & $\begin{array}{l}\text { Statements indicating students' awareness of their process: strength and } \\
\text { weaknesses, aspects they have to pay attention to, knowing what is useful, } \\
\text { difficult or easy, e.g., "That is one of the most difficult exercises for me." }\end{array}$ \\
\hline \multicolumn{2}{|l|}{ Strategies } \\
\hline Keeping records & $\begin{array}{l}\text { Statements indicating student-initiated efforts to record events and to make } \\
\text { notes. }\end{array}$ \\
\hline Organising & $\begin{array}{l}\text { Statements indicating student-initiated overt and covert (re)arrangements of } \\
\text { strategies and approaches to improve task performance, e.g., "I work from } \\
\text { left to right until the end." }\end{array}$ \\
\hline Learning & $\begin{array}{l}\text { Statements indicating strategies students use to remember information more } \\
\text { easily and revise for a practical exam, e.g., "I talk to myself, and then I can } \\
\text { remember it better." }\end{array}$ \\
\hline Problem-solving & $\begin{array}{l}\text { Statements indicating students' problems and the way they deal with them e.g., } \\
\text { "First, I try to solve it by myself." }\end{array}$ \\
\hline Structuring the environment & $\begin{array}{l}\text { Statements indicating student-initiated efforts to select or arrange the physical } \\
\text { setting to make learning easier, e.g., "I choose a quiet place." }\end{array}$ \\
\hline $\begin{array}{l}\text { Seeking and selecting } \\
\text { information/material }\end{array}$ & $\begin{array}{l}\text { Statements indicating student-initiated efforts to seek and select task-related } \\
\text { information and material from non-social sources, e.g., "I can find the } \\
\text { necessary information in the protocol." }\end{array}$ \\
\hline \multicolumn{2}{|l|}{ Social interaction } \\
\hline $\begin{array}{l}\text { Seeking social } \\
\text { assistance }\end{array}$ & $\begin{array}{l}\text { Statements indicating student-initiated efforts to seek, give or receive help } \\
\text { from a) peers and b) teachers. This category was further divided into social } \\
\text { interactions concerning material, content, performance and process matters. }\end{array}$ \\
\hline Help-seeking choice & $\begin{array}{l}\text { Statements indicating that students make choices in selecting a peer or teacher } \\
\text { to ask for help. }\end{array}$ \\
\hline Help-seeking emotion & $\begin{array}{l}\text { Statements indicating students' feelings about seeking help, e.g., feeling } \\
\text { comfortable or embarrassed to ask for help. }\end{array}$ \\
\hline Proactive help seeking & Statements indicating student-initiated efforts to receive the help they need. \\
\hline \multicolumn{2}{|l|}{ Motivation } \\
\hline Persistency & $\begin{array}{l}\text { Statements indicating that students do not give up when facing difficulties } \\
\text { during task performance; they exhibit resilience. }\end{array}$ \\
\hline Self-efficacy & $\begin{array}{l}\text { Statements indicating students' judgments of personal capabilities to execute } \\
\text { the task successfully and achieve their aims. }\end{array}$ \\
\hline Goals & $\begin{array}{l}\text { Statements indicating students' professional goals they strive for e.g., "I want } \\
\text { to become an electrician." }\end{array}$ \\
\hline $\begin{array}{l}\text { Professional } \\
\text { development }\end{array}$ & $\begin{array}{l}\text { Statements indicating professional development activities outside school, e.g., } \\
\text { "Every Saturday, I work at a hairdressing salon." }\end{array}$ \\
\hline Deliberate practice & $\begin{array}{l}\text { Statements indicating student-initiated efforts to practice certain skills in order } \\
\text { to improve. }\end{array}$ \\
\hline
\end{tabular}


observational notes were input for the first part of the interview, but were not part of the analysis.

An inductive-deductive method was used to develop the coding scheme for analysing the interview data. Based on prior research (Jossberger et al. 2010; Zimmerman and Martinez-Pons 1986), categories of SRL and motivation were identified to analyse the interviews (see Table 3). The coding scheme was tested and readjusted over a few iterations. The first author informed the second author about the coding scheme and procedure. Parts of the data were analysed together to ensure familiarity with the material. Then, each rater conducted individual analysis. In cases of doubt, the raters discussed the data together. To establish inter-rater reliability, the first and second authors coded approximately $20 \%$ of the interviews and interactions. With a Cohen's kappa of .77, the inter-rater agreement was considered substantial.

A cross-case analysis was performed to construct an elaborate matrix that permitted a systematic comparison of the 18 participants identifying similarities and differences in SRL activities. The basis for the cross-case matrix was the interview data. The matrix allowed us to reconcile individual students' uniqueness and gain a deep understanding of the generic processes that occurred among students (Miles and Huberman 1994). As in the analysis of the interviews, the first author provided background information and explained the coding procedure. Then, the first author and a student assistant scored the strategies for orienting, planning, monitoring, adjusting, evaluating and reflecting using the cross-case matrix. They identified three different rating options: high value $(++)$, medium value (+), and low value (-). If regulation activities were observed and indicated during an interview, the student received a high value or a medium value, depending on the nature and frequency of the activity. If regulation activities were not

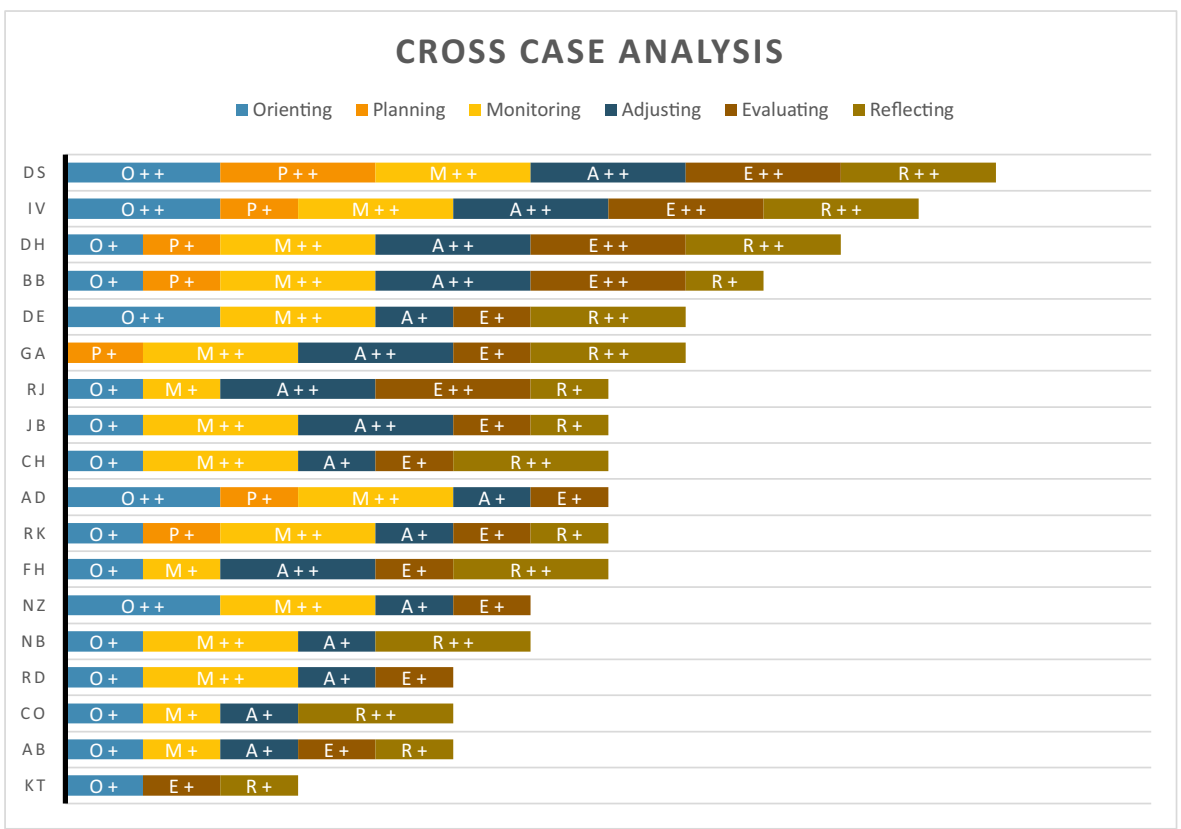

Fig. 1 Cross-case analysis 
observed or inconsistencies were documented, the student received a low value. The raters had an agreement rate of 98 per cent. The scores were used to create student profiles, and the students were ranked accordingly (see Fig. 1).

In addition to the interview data, the interaction data provided information on the students' social interactions during task performance. Student-initiated efforts to seek help from peers and teachers and give help to peers were coded, as were teacher- and peer-initiated helping behaviours. This coding made it possible to gather knowledge about the direction of the interactions. Furthermore, the reasons for the interactions were coded, and distinctions were made in interactions that concerned material, content, performance and or process matters. The interactions were counted.

The questionnaire was analysed with a paired sample t-test to compare the means of the two scales within each topic. We used a one-tailed test, as we expected that students in our sample would score significantly higher on the deep processing, internal regulation, learning as knowledge building and intrinsic motivation scales. Moreover, Pearson's correlation coefficient was calculated for the ILS-SVE variables.

Finally, the self-reported internal regulation was compared to the qualitative data to estimate participants' self-assessment. The participants were ranked according to their self- reported scores (srs) and their rankings in the cross-case matrix. The difference between ranks indicated a good self-assessment, an overestimation or an underestimation. A value between negative four and positive four was considered a good selfassessment (see Table 6).

\section{Results}

First, the interview and interaction data are described to zoom in on students' SRL and motivation during practical task performance. These findings are organised along the preparation, execution and completion phases. Second, students' preparations for learning and future vocations are presented. Students' quotes are used as illustrations, and participants are identified by unique codes. Finally, the results of the self-reports are linked to the qualitative data.

\section{Self-Regulated Learning during Practical Task Performance}

\section{Preparation Phase}

Orienting Of the sampled students, 17 oriented toward the task by reading the task description or studying a drawing carefully in the beginning to understand what was expected. They activated their prior knowledge and checked whether everything was clear. For instance, one of the pharmacy assistants was tasked to make ointments $(A D$ : 'I read the whole task first because then I know what to do and what materials I need.'). In the case of one student, orienting was not visible, as he continued with a task he had started during a previous lesson.

Planning Preparations for task execution in terms of planning time and resources were visible in several ways. Planning activities were observed in seven students. The carpentry student, who was making a table, explicitly mentioned that he had set a goal 
(GA: 'I had the goal to finish something during the lesson, and I succeeded.'). At least four students paid close attention to their working time (RK: 'I checked my watch to see how much time I had left before we had to start cleaning up.'). The students enrolled in laboratory technology negotiated the use of resources (such as the $\mathrm{pH}$ meter and the burette) and made agreements with peers (CH: 'We discussed the order in which to use the instruments.').

Moreover, most students claimed that they knew the steps they had to take during their task performance. In practice, knowing the order of steps generated a rough overview rather than a detailed plan, which sometimes led to future problems. For instance, the cook in training said that he had made a mental plan by thinking through the different steps of the recipe before beginning the task. However, during his task performance, he realised that his planning was not good enough (FH: 'Before I started to cut the vegetables, I wondered whether I should start with that or whether I should make the mushroom sauce first. Well, yes, that was actually the point in time when it went wrong. I should have started with the mushroom sauce, but I decided to cut the vegetables first. I thought that cutting the vegetables would take longer and I forgot about the fact that the mushroom sauce had to be on the stove for 20 minutes...'). Unlike the other educational tracks, cooking is a dynamic domain in which detailed planning is essential to succeed in the preparation of the food. In the other educational tracks, though planning might enhance a considered approach, not planning carefully may have less devastating consequences. In this study, no student worked out an elaborate written plan including goals, sequences and timings for the practical task. Further, nine students explicitly indicated that they did not do any planning (NZ: ' $I$ decide on the run most often. See if it works out and otherwise improvise.').

Structuring the Environment In all, 15 students preferred calm and quiet surroundings, and 10 explicitly mentioned and showed how they structured their environment according to their preferences by 'selecting a specific workplace'; 'telling peers to wait a moment, to stop disturbing, to keep on working, to calm down, or to keep quiet'; 'putting away disturbing objects'; or 'working with a headset'. The student enrolled in goldsmithery (DS) said, 'We can choose where to sit ourselves, and at first, I was sitting next to Peter, but I got annoyed. Therefore, I decided to move to another table, and now, it is fine. Every table has its own people from totally crazy to concentrated.' NB, one of the medical receptionists in training, indicated, 'It is always important that I am not sitting next to people I am having a too good time with because I am very quickly sociable and easily distracted. Thus, I usually try to find a quiet place.' Finally, three students did not have an environmental preference, but indicated that they focused on their task and did not mind the surroundings.

\section{Execution Phase}

Monitoring Task execution was a continuous process of doing, checking and adapting (e.g., comparing a drawing of an electrical circuit with own performance). Of the students, 17 paid attention to their product in preparation inspecting the product constantly to check whether they were still doing well and to prevent mistakes. The following two examples from the electro-technology programme illustrate the students' 
monitoring activity: (RD: 'I checked the different switches first to see if one is broken because, if you start without checking it, you will have a problem later on when you have programmed everything.') and (IV: 'Mostly, I check to verify whether I have used the right codes because, sometimes, I am wrong. Some time ago, I wrote down 21 although it should have been 22, so I check the drawing to see if it is correct what I am doing.'). The student enrolled in hairdressing was performing a permanent wave for which she had to use hair rollers. When using hair rollers, the section of the hair should be about the size of the roller. RK indicated, 'When I roll up a hair roller toward the scalp, I check whether it is fixated and no longer slides. I also check that the section of the hair is well enough included.'

Organising The findings showed that 15 students used strategies to organise their processes during task performance and followed a sequence of steps. Both the number of strategies and the specificity of patterns varied. One of the electro-technology students (IV) indicated that he used colour combinations, worked from left to right, finished one part first before proceeding to another and usually worked on tasks in order from the easiest to the most difficult. The carpentry student (GA) said that he numbered materials to know where they belonged, marked the top of a wooden plank (which he did not sandpaper), organised his toolbox and transformed his workplace by putting two tables together. The pharmacy assistants (AD and $\mathrm{DH}$ ) mentioned that they ticked off actions they had already performed to know where they were in their process. The hairdresser (RK) explained that she worked from left to right and from front to the back and used wrappers of different colours. Only three students did not mention using strategies to organise their work.

Adjusting and Persisting Monitoring sometimes led to larger adjustments to strategies and performance. When students realised that the product did not yet meet their expectations, they improved it by using another tool, doing certain steps over again, changing and correcting parts of the product or adjusting their approach. All students indicated that they tried to improve their task performance by themselves if they were not yet satisfied with their product ( $R K$ : 'When I realise that a curling pin is too loose, I roll it out and then I roll it in again, but tighter so that it is better fixated.'; GA: 'It was not totally straight, so I had to chop a bit more.'). Most $(\mathrm{n}=17)$ of the students were careful when adjusting delicate products to prevent making irreversible mistakes or time-intensive repairs and adjustments. Moreover, they mentioned not giving up easily when facing difficulties (DE: “'Does not work” does not exist.'). Of the students, nine had already experienced a difficult situation in which they had struggled with their task performance and had been close to giving up. In these situations, the students took a break or asked for advice and then moved on in the current or next lesson. The following example, in which an electro-technology student failed in his first attempt, illustrates how students dealt with and learned from their tasks (DS: 'Last semester, a task did not work out as planned. It was a music ball. You had to make a sound box, which was a lot of work. I managed that, and when everything was ready, I realised that I had forgotten to put the jingle bell inside. So, I had to open the solder, but afterwards, it was totally deformed, and I had to start all over again. Now, I am doing it in the evening hours, and I am having a hard time because I do not like it. But I am doing it over.'). 
Keeping Records Seven students used artefacts to support task execution and prevent errors. They made notes during the observed practical task performance for different reasons (e.g., to keep records, track and order, to structure, to visualise or to prepare). For instance, three electro-technology students (IV, RD and RJ) made drawings to visualise the electric circuit, and two made additional notes of the colours of the wires to know what needed to be connected. The two pharmacy assistants labelled their different ingredients to maintain correct records. Moreover, the laboratory assistant $(\mathrm{CH})$ wrote down formulas that the teacher explained. These formulas were not clearly described in the textbook, and keeping records in her notebook allowed the student to reference the information later during the task performance. Finally, one of the automotive engineering students (NZ) used a coloured marker to underline important parts of the text, indicating that this helped him with both preparation and reference.

Seeking and Selecting Information/Material All the students indicated that they knew where to find the materials or information necessary for their tasks (e.g., a drawing, a recipe or the task description). They tried to solve any knowledge gaps by themselves first before seeking social assistance.

Social Interaction Students said they sought social assistance when they did not know how to proceed, had doubts and needed confirmation concerning their process or product or wanted more information (NZ: 'I had a hunch, but I was not completely sure if there were more possibilities.'; DS: 'Yes, that was with the cutting machine. I did not see the zero, and I adjusted the machine incorrectly. I thought that could not be correct, and so I decided to ask the teacher.'). All the students indicated that they initiated efforts to receive necessary help because they wanted 'to know how everything works', 'to learn', 'to be able to proceed', 'to prevent or correct mistakes', 'to perform well', 'want certainty', 'to receive a good explanation', 'to solve the problem and answer the question' and 'to understand well'. The majority (16 students) also felt comfortable asking a teacher or peer for help because they thought asking questions was part of the learning process ( $A B$ : ' $I$ think it is better to ask because, I mean, you are at school to try to learn things.'; KT: 'It is something in me. Some say "Well, I do never dare to ask," and then I think, “Don't be a fool, just ask.” That's it.'). Further, six students explained feeling comfortable due to their own self-confidence and having a nice class with a good atmosphere. Two students (JB and AB) reported having experienced situations in which they felt uncomfortable asking for help due to a bad relationship with the teacher. Moreover, all students mentioned knowing whom to ask for help or for answers. A good personal relationship and the expectation of receiving a correct answer were considerations when consulting a peer (RJ: 'I consult someone who knows a lot, not someone who knows very little.'). Interestingly, 11 students indicated that asking a peer for help was usually faster, as the teacher was often busy; however, if the teacher was available, they consulted the teacher directly.

The results obtained from the interaction data enriched the interview data regarding the direction and range of social interaction during the practical task performance (see Table 4). Although the methods of interacting differed across students, their students' self-initiated efforts showed that they chose to consult teachers more often than peers and that, in many cases, help-seeking was mainly around material issues. When 
Table 4 Direction and range of social interaction during task performance

\begin{tabular}{llllll}
\hline Direction & Content & Feedback & Material & Process & Total \\
\hline Seek help from peer & $0-3(13)$ & 0 & $0-12(46)$ & $0-5(20)$ & 79 \\
Seek help from teacher & $0-10(24)$ & $0-4(20)$ & $0-4(36)$ & $0-8(44)$ & 124 \\
Give help to peer & $0-4(13)$ & $0-3(12)$ & $0-11(25)$ & $0-18(76)$ & 127 \\
Receive help from peer & $0-1(2)$ & $0-2(4)$ & $0-4(5)$ & $0-2(4)$ & 15 \\
Receive help from teacher & $0-18(50)$ & $0-7(25)$ & $0-3(15)$ & $0-24(92)$ & 182 \\
\hline
\end{tabular}

The number in brackets indicates the totals

students approached teachers for help, the teachers obliged and also offered assistance which extended beyond what students had initially asked for. additional help for which the students did not initially ask. Thus, taking initiative often resulted in teacherinitiated helping actions.Moreover, participating students helped peers more often than they received help from peers.

\section{Completion Phase}

Evaluating To evaluate their performance, students mentioned using different sources of information: 5 students used more than one source to evaluate their performance. Sixteen students said that their products revealed how they performed (BB: 'The electrical circuit was working correctly.'; FH: 'The sauce was a bit too salty.'; NZ: 'The motor ran better.'; GA: 'The corners were at the right angles.'). Four electrotechnology students indicated that they evaluated their performance by comparing it with given assessment criteria. A carpentry student mentioned that he compared his performance with that of a peer. Further, two students considered their process when evaluating ( $\mathrm{CH}$ : 'Everything went well, and I did not experience any problems.'). For eight students, the teacher was an important source in the evaluation process (KT: 'Teacher finds it good.'). One student mentioned exam results as an additional indicator. Finally, one medical receptionist student (CO) checked whether she had performed all the steps in a procedure (in this case, the audiometry and cleaning of the ears). She did not mention how she evaluated whether she had performed these steps well.

Reflecting Students reflected on aspects they wanted to improve, and 15 of them showed an awareness of their own weaknesses and indicated what they found easy or difficult. While 15 students mentioned very task-specific and/or behavioural aspects they had to pay attention to or wanted to improve, three also focused on semi-long-term goals. For instance, the cook in training (FH) mentioned that he wanted to improve his planning, develop a sense of taste and improve his cutting techniques. A further four students mentioned that they needed to continuously improve and perfect their skills, naming a variety of domain- specific aspects. For instance, one of the medical receptionists (CO) indicated that she wanted to gain more in-depth knowledge of diseases to 
improve her skills in giving explanations to patients. The equine management student $(\mathrm{AB})$ thought she needed to learn various mundane facts about the equestrian sport and to dare to push the limits. Finally, three students did not mention any particular aspects of improvement.

\section{Preparation for Learning and Future Vocation}

Motivation to Learn and Practice In all, 14 students indicated that they learned most from hands-on experiences, noting that practising and performing a practical task themselves helped them remember (JB: 'Practice is easy for me. I do not need to study. I practice at school, and teachers say that I have technical insight.'). The approaches students took in studying for practical exams included 'reading', 'making notes and summaries of the most important aspects', 'rehearsing and testing one's knowledge by questioning', 'studying material (e.g., a drawing) and deciding on what to do and how to do it', 'learning necessary steps and procedures by heart', 'asking professionals for explanations' and 'practicing and preparing at home'. Interest and motivation led students to engage in practice and rehearsal; however, they did not explicitly say that they practised improving their skills. Only three students mentioned that they practised skills in and out of school to improve their performance (CO: ' $I$ experienced problems with applying a certain bandage. Actually, it is a rather easy one, but I did not really master that one. So, I practised it a thousand times and, at the end of the lesson, I was able to do it, but I need to rehearse regularly; otherwise, I forget how it works.').

Furthermore, 10 students indicated that they regularly engaged in professional activities outside VET and expressed an intrinsic motivation, enjoyment and drive to experiment, investigate, work, create or repair. For instance, the hairdressing student said that she colours and styles the hair of her mother and friends in her leisure time because she enjoys experimenting with hair and styling people. Similarly, three electrotechnology students and one automotive engineering student worked regularly with their fathers, who were employed in their fields of interest. All 10 students stressed that interest was their primary aim when engaging in these professional activities, and four also noted it was a way of earning money.

Goals and Self-Efficacy When talking about their long-term goals, 15 students expressed extrinsically motivated goals, stating that their first aim was to earn their degree and finish vocational education successfully. Furthermore, students elaborated on their professional future. Thirteen students had intrinsically motivated professional goals ranging from more general to more specific. A more general goal was to continue with higher professional education to specialise further in the domain of interest. The student involved in goldsmith training proposed a more specific goal to travel after graduation to explore art and different styles and to refine and develop her own style before starting her business. Students' statements illustrated that they seemed rather convinced of achieving their aims (RJ: 'Definitely.'; KT: 'I can do it.'; CO: 'I do think I have the commitment.'). A handful (five students) used more careful formulations, such as 'I think so' and 'I hope so', but no student expressed serious doubts. Students were also convinced of performing well in their tasks. Only one student indicated that she was often afraid to make a mistake, though during the observed lesson, she achieved the best result. 
Table 5 Results of the ILS-SVE

\begin{tabular}{|c|c|c|c|c|}
\hline \multirow[t]{2}{*}{ Scales } & \multirow[t]{2}{*}{ M } & \multirow[t]{2}{*}{$\mathrm{SD}$} & \multicolumn{2}{|c|}{ Comparison of pairs } \\
\hline & & & $\mathrm{t}$ & $\mathrm{p}$ \\
\hline \multicolumn{5}{|l|}{ Processing strategies } \\
\hline Deep $(\alpha=.66)$ & 3.60 & 0.47 & 2.81 & .01 \\
\hline Shallow $(\alpha=.89)$ & 3.10 & 0.78 & & \\
\hline \multicolumn{5}{|l|}{ Regulation strategies } \\
\hline Internal $(\alpha=.76)$ & 3.27 & 0.56 & 2.09 & .03 \\
\hline External $(\alpha=.82)$ & 2.86 & 0.63 & & \\
\hline \multicolumn{5}{|l|}{ Learning conceptions } \\
\hline Knowledge building $(\alpha=.61)$ & 3.75 & 0.41 & 3.35 & .00 \\
\hline Intake of information $(\alpha=.90)$ & 3.10 & 0.76 & & \\
\hline \multicolumn{5}{|l|}{ Motivational orientation } \\
\hline Intrinsic $(\alpha=.77)$ & 4.61 & 0.41 & 2.11 & .03 \\
\hline Extrinsic $(\alpha=.79)$ & 4.31 & 0.64 & & \\
\hline
\end{tabular}

The significant values are displayed in bold

\section{The Self-Reports and how they Relate to the Qualitative Findings}

Table 5 presents the results of students' self-reports on the ILS-SVE questionnaire. The paired sample t-test revealed that all pairs differed significantly according to what we could expect from this sample of well-performing students. They used more deep than shallow processing strategies $(t(17)=2.81, p<.05, r=.56)$; more internal than external regulation strategies $(t(17)=2.09, p<.05, r=.45)$; focused more on knowledge building than on intake of information $(t(17)=3.35$,

Table 6 Pearson correlations between the ILS-SVE variables

\begin{tabular}{|c|c|c|c|c|c|c|c|c|}
\hline Variable & 1 & 2 & 3 & 4 & 5 & 6 & 7 & 8 \\
\hline 1. Deep processing & - & & & & & & & \\
\hline 2. Shallow processing & .35 & - & & & & & & \\
\hline 3. Internal regulation & .46 & .23 & - & & & & & \\
\hline 4. External regulation & .23 & .39 & .04 & - & & & & \\
\hline 5. Knowledge building & .45 & .50 & .72 & .26 & - & & & \\
\hline 6. Intake of information & -.18 & .30 & -.10 & .53 & .11 & - & & \\
\hline 7. Intrinsic motivation & -.05 & .36 & .07 & .22 & .23 & .47 & - & \\
\hline 8. Extrinsic motivation & -.00 & .19 & -.27 & .33 & -.10 & .45 & .42 & - \\
\hline
\end{tabular}

Correlation coefficients presented in bold are significant $(p$ (two-tailed) $<.05$ ). $N=18$ 
$p<.01, r=.63)$; and were more intrinsically than extrinsically motivated $(t(17)=$ $2.11, p<.05, r=.46)$.

Table 6 depicts the correlation matrix and reveals four significant correlation coefficients. There were significant relationships between knowledge building and shallow processing $(r=.50, p$ (two-tailed) $<.05)$; knowledge building and internal regulation $(r=.72, p$ (two-tailed $)<.01)$; intake of information and external regulation $(r=.53, p$ (two-tailed) $<.05)$; and intrinsic motivation and intake of information $(r=$ $.47, p$ (two-tailed) $<.05)$.

A closer examination of the regulation strategy scales revealed that students reported relying and depending less on the teacher. In the interviews, students expressed that help- seeking was part of their learning process, but they also said that they tried to work as independently as possible. The interaction data showed that students preferred to contact the teacher, although they mentioned that seeking help from a peer was usually faster.

The student profiles based on the cross-case analysis show that four students went through the micro processes of orienting, planning, monitoring, adjusting, evaluating and reflecting. All students except one showed micro cycles of monitoring and adjusting. The profiles and rankings are depicted in Fig. 1, which shows that the students differed in SRL. Both the student with the highest SRL level (DS) and the one with the lowest SRL level (KT) are described as portraits (see Appendix 2).

Table 7 Comparison of self-report score (srs) on internal regulation and cross-case analysis (CCA)

\begin{tabular}{|c|c|c|c|c|c|}
\hline Participant & Score ILS & Ranking ILS & Ranking CCA & $\begin{array}{l}\text { Difference between } \\
\text { ranking scores }\end{array}$ & $\begin{array}{l}\text { Estimation } \\
\text { of self-assessment }\end{array}$ \\
\hline & & (XR) & (YR) & $(\mathrm{d}=\mathrm{XR}-\mathrm{YR})$ & \\
\hline KT & srs $>4$ & 1 & 18 & -17 & $\mathrm{OE}$ \\
\hline RK & & 2 & 9.5 & -7.5 & $\mathrm{OE}$ \\
\hline $\mathrm{RD}$ & $\mathrm{srs}>3.5$ & 3 & 16 & -13 & $\mathrm{OE}$ \\
\hline $\mathrm{BB}$ & & 4 & 4 & 0 & + \\
\hline DS & & 6 & 1 & 5 & $\mathrm{UE}$ \\
\hline $\mathrm{FH}$ & & 6 & 9.5 & -3.5 & + \\
\hline $\mathrm{DE}$ & & 6 & 5.5 & 0.5 & + \\
\hline RJ & srs3 & 9 & 9.5 & -0.5 & + \\
\hline $\mathrm{AD}$ & & 9 & 9.5 & -0.5 & + \\
\hline $\mathrm{CH}$ & & 9 & 9.5 & -0.5 & + \\
\hline NB & & 11 & 13.5 & -2.5 & + \\
\hline $\mathrm{AB}$ & & 12 & 16 & -4 & + \\
\hline $\mathrm{NZ}$ & & 13.5 & 13.5 & 0 & + \\
\hline IV & & 13.5 & 2 & 11.5 & UE \\
\hline $\mathrm{CO}$ & $\operatorname{srs}<3$ & 15.5 & 16 & -0.5 & + \\
\hline GA & & 15.5 & 5.5 & 10 & UE \\
\hline DH & & 17.5 & 3 & 14.5 & UE \\
\hline JB & & 17.5 & 9.5 & 8 & UE \\
\hline
\end{tabular}

$O E$ overestimation; $U E$ underestimation; + good self-assessment 
Comparing the cross-case table with the self-reported internal regulation revealed that 10 students had good self-assessments, while three students tended to overestimate and five tended to underestimate their internal regulation (see Table 7).

Finally, the self-report questionnaire revealed that students were highly motivated, both intrinsically and extrinsically. Furthermore, in the interviews, the students expressed their personal interest in various subjects and their enjoyment of developing skills, which was evident in their goals and professional activities. At the same time, students stressed the instrumental value of their education (e.g., receiving a certificate).

\section{Discussion}

In this study, we explored SRL behaviours in VET and described micro processes associated with planning, monitoring and evaluating during practical learning tasks. We wanted to discover how vocational students self-regulate their learning during practical task performance and what they do to improve themselves professionally. By taking a qualitative mixed-method approach, we were able to examine students' behaviours and thoughts of SRL in VET, a context and population that is still underexplored. VET differs from academic settings in that learning by doing is crucial, and skills like SRL support the process of getting the most out of these learning situations. We gained an understanding of what well-performing vocational students already do and ways they can improve and develop further. Our data show that the students who participated in this study self-regulated their learning, but in remarkably different ways.

We distinguished task performance into the three phases of preparation, execution and completion and examined students' learning and preparation for their future vocations outside school. In the preparation phase, students generally began working on their practical task immediately and oriented themselves by checking what needed to be done. Students indicated that they knew the steps to be taken during task performance, and we observed some planning regarding time and resources. Students did not make elaborate plans including goals, sequences or timing, but they actively tried to select an ideal workplace suited to their own needs and personal preferences. Research has shown that skilful learners set specific goals that focus on learning (Ertmer and Newby 1996; Zimmerman 2005, 2006, 2013), but the students in our study rarely set explicit goals and, if they did, set goals related to task performance rather than learning. However, they did deliberately practise on incidental occasions and in extracurricular activities.

In the execution phase, monitoring appeared to be an activity that the students executed regularly by keeping a close eye on the products on which they were working. As students concentrated and focussed their attention on their tasks, they were able to detect (emerging) mistakes during the process. By completing the executed steps numerous times if necessary and making adjustments, they were often able to correct their own mistakes and improve their performance. Students' careful monitoring also helped them determine at what point during task performance they needed to seek help, and they said they knew where and how to find the necessary information. Students only consulted the teachers when they had doubts and needed confirmation or when they wanted more information or materials; otherwise, when they wanted to get a quicker response, they consulted a peer with enough knowledge to help them. In general, students experienced no distress in help-seeking. They were proactive and considered 
teachers and peers as sources of social support in learning. It is important for students to take initiative to seek assistance when they face difficulties instead of being passive, giving up or persisting unsuccessfully. Previous research has shown that self-regulated learners show adaptive help-seeking behaviours. Highly self-regulated learners see the value of external support and, therefore, seek help more readily than poorly selfregulated students (e.g., Newman 2002; Zimmerman and Martinez-Pons 1986).

In the completion phase, the product or outcome was most crucial for students' selfassessment of their performance. This is not surprising, as the teachers' assessments were also largely based on these results. Moreover, in most cases, the product was a physical object - something they could see and touch and, therefore, easily test and inspect. This work product might be seen as an epistemic object, a resource for knowledge and action (Nerland and Jensen 2012). This resource was relevant for VET students' learning by doing, which clearly differs from academic settings. It was a means of working, as it helped students understand their own processes. Students' own learning and working processes were considered far less often in the evaluation process. That is, it was mentioned only a few times. In general, product and process are closely intertwined, as the product is the result of the process. However, evaluating one's own process goes beyond assessing the product. It is a meta-cognitive skill that enables students to effectively detect and deal with errors and improve their performance.

Analysing error causes can help prevent them in the future, and learning from mistakes can evoke new insights for future task performances. Knowing what not to do in a certain situation has been called negative knowledge, and it is considered beneficial for learning as long as individuals can first identify suboptimal or incorrect actions to prevent future errors and learn from their experiences (Harteis et al. 2008). Taking process information from previous task performances into account when looking ahead is a reflective process. The vocational students in this study reflected on aspects they wanted to improve, indicating a certain awareness of their processes. However, they regulated their performance more than their learning. These findings are similar to those of studies on professional learning in the workplace. For instance, teachers tend to self-regulate their teaching rather than their learning, and practice is seen as a stimulus for reflection and a motivation to learn (Lindblom-Ylänne et al. 2011; van Eekelen 2005). Similarly, in the domain of medicine, research has found that the focus lies on professional performance goals, rather than competence improvement goals (van de Wiel et al. 2011).

Student motivation is both a starting point and an outcome of self-regulation processes. During task performance and beyond, students were driven by their motivation. They were willing to work and make an effort, and they did not give up easily when facing problems or difficulties. In an empirical study, perseverance of effort was a positive predictor of students' SRL and academic performance in college (Wolters and Hussain 2015). Some of the students in our study strived for perfection and practised deliberately to improve their skills. Intrinsic motivation and, to a lesser degree, extrinsic motivation were the reasons for engaging actively in vocational activities. Students reported both extrinsic and intrinsic goals. The fact that most of the students mentioned the extrinsic goals (e.g., receiving a certificate) first shows that they considered their chances of entering the labour market. Certainly, for this target group, receiving a certificate was crucial. Moreover, the students reported high self-efficacy concerning 
their task performance and future goal achievement (cf. Pintrich 1999, 2003). We cannot evaluate how realistic or optimistic their self-assessments were, but it seems that they believed in their capacities and tried to make their vocational dreams come true.

The students' self-reports confirmed their high motivation and showed that they were trying to build personal repertoires of knowledge and skills, take responsibility for their learning progress and connect different pieces of information by finding links and integrating new information and prior knowledge. Although the students identified these approaches in the interviews, it became clear that learning by doing and trial and error strategies also played essential roles in practice, indicating a less strategic regulation approach. The students' profiles illustrated how they differed. Although all were good students, only a few completed all the steps of SRL. The explanation for these differences may lie in either the students or their assigned tasks. Linking the selfreport scores to the profiles generated by the cross-case analysis suggests that the students were rather good at self-assessment.

\section{Limitations and Future Research}

Using multiple data sources allowed us to describe SRL behaviours across diverse professional domains in VET. Although we tried to capture detailed accounts, we still might have missed certain aspects. Ours was a small-scale study comprising wellperforming student volunteers nominated by their teachers. This selection bias was built in to learn from the SRL behaviours present in VET. It is possible that the students gave socially desirable answers or tried to act well. However, the use of different qualitative methods prevented a unilateral perspective. In addition, this particular group of students was not used to participating in scientific research, which might have led to more honesty. Each student was observed only once, and the pure presence of the researcher might have influenced the students' behaviour. However, we did not have the impression that students felt uncomfortable, and, as no interaction took place during the lesson, it seemed the students forgot about the researcher over time.

The ILS-SVE questionnaire was used to examine how students rate themselves on variables related to our research question. Of the scales, 'deep processing' and 'knowledge building' had low reliability (.66 and .61, respectively). However, as we did not use the questionnaire for either individual diagnostic purposes or measuring learning styles, we considered the value to be sufficient. The correlation matrix revealed that four scales were significantly correlated. Of the correlation coefficients, three were rather low, and one was high (.72), potentially indicating too much overlap between the 'internal regulation' and 'knowledge building' scales.

Finally, yet importantly, our study took place across diverse vocational training tracks and, therefore, was not homogenous with regard to the setting. All students were engaged in practical tasks in which learning by doing played an essential role. The sample was by no means representative of either the general population or the group of well-performing students, and the results cannot be generalised.

Future research is needed to continue the on-line investigation of actions and behaviours related to SRL and how these influence learning and performance in VET. In this study, we focused on well-performing students. It would be interesting to investigate which SRL behaviours weaker VET students apply, where they fall short, 
and difficulties they face. It is likely that regulating motivation plays a crucial role. Moreover, research on designing and testing instructional means to support the development of SRL skills in VET is needed.

\section{Conclusion and Practical Implications}

VET strives to create independent and self-directed learners, and we have argued that SRL is a promising skill for accomplishing this aim. Learning from practice and experience without reflection seems insufficient. Integrating experiences and making meaning of them in relation to one's own professional knowledge base is considered more effective (Ericsson 2018). Although the well-performing vocational students in our study self-regulated during practical task performance, the results show considerable room for skill improvement. In particular, planning seemed difficult and was not closely linked to previously defined goals. Further, not all students evaluated or reflected on their performance or deduced consequences for future task performance. It seems important that students be confronted with challenging tasks that encourage them to apply SRL skills. If tasks are too easy, planning might not be necessary, and evaluation and reflection may appear trivial.

Actively promoting students' use of specific processes and guiding their learning in systematic practice activities can further improve their performance (Ericsson 2018; Zimmerman 2006). Therefore, it seems important that teachers are aware of SRL and know how to support their students in practical task performance. As vocational teachers do not feel they are well prepared to provide appropriate instructional means for their students (Jossberger et al. 2015), heuristics for practice (Winne 2018) and an awareness of processing can create opportunities to adapt (Panadero et al. 2016). Moreover, explicitly helping students see how they learn can be beneficial (Winne 2018). Well-performing students, for instance, could explicate and demonstrate their strategies to weaker students to help them learn. Teachers can also function as models and engage in co-regulation to enable or enhance planning, monitoring and evaluating during practical task performance.

Acknowledgements The authors would like to thank the three anonymous reviewers for their detailed reviews with suggestions for improving this paper. Moreover, the authors would like to thank Cathrin Rothkopf for her assistance in scoring. The research was funded by NWO.

\section{Appendix 1}

\section{Semi-structured interview (translated from Dutch to English)}

\section{Introduction}

I would like to start with the interview. In the interview, I will ask you questions about today's task performance and your task approach. There are no good or bad answers. I simply want to learn more about your individual way of working. I would like to record the interview in order to process the data later on, and I am not able to remember 
everything. That means that you have to speak clearly. Your data is anonymous. Do you agree with that? Do you have any questions?

\section{Part I: Discussing individual task performance and activities based on the observations (example questions)}

First, I would like to talk about your lesson today.

Opening question: Tell me, how did you find the lesson was going today?

- Way of approach (e.g., strategy use, planning): How did you approach the task? Why did you do it in that way? What did you do next? Why did you do it that way?

- Strategy use when problem solving: What kind of problem did you come across at that particular moment? Why? How did you solve it? Why did you do it that way?

- Social interaction: I saw that you went to the teacher/fellow student. What did you ask/say? Why did you choose to contact him/her?

- Adjusting: Did the response/feedback of the teacher/fellow student lead to adjustments? What kinds of adjustments? Why or why not?

- Evaluation, reflection: How did you like today's task? Did you find it useful?

Did you find it difficult or easy? Why?

- Self-efficacy: When you started working on the task, did you think that you were able to perform well on the task? Did you have the feeling that you could do it?

\section{Part II: General approach}

- General approach: Was this a usual approach in today's lesson, or did you approach the task differently than you normally do?

- Strategy use: How do you prepare for a (practical) exam?

- Strategy use when problem solving: Do you experience difficulties/problems during task performance? What do you do? What do you do if you do not succeed?

- Monitoring, evaluation, reflection: How do you tell that something is working well or not?

- Seeking and selecting information: Do you know where to find the information you need? How do you do that?

- Help seeking: In which situations do you choose to ask someone for help?

Who do you ask for help (teacher/fellow students)? Where do you look for help? Do you feel comfortable asking for help? Why? Why not? Are there teachers/fellow students you do not ask for help? If yes, why not?

- Proactive behaviour: Do you take steps (exert effort) to receive help from teachers/ fellow students? If yes, why and how? If no, why not?

- Evaluation, reflection, work attitude: What do you do if you are not satisfied and want to do it better? What do you do if you perform very well/very badly? Do you know what to pay attention to during a lesson?

- Evaluation: How do you finally evaluate whether you have performed a task correctly?

- Work attitude e.g., persistency: Do you give up sometimes? Why? What happened in that situation? 
- Self-determination: What or how much are you allowed to choose yourself in your VET? Are you allowed to choose tasks yourself?

\section{Part III: Motivation and professional development}

Last, but not least, I would like to ask you some final questions about your motivation.

- Motivation: How do you like your VET? Is it as you expected it to be?

- Strategy use: What do you find particularly important to improve in your craft? From what do you profit most? Why?

- Environmental structuring: What is important for you in order to work/learn well?

- Goal orientation: What are the most important goals that you want to reach at school and with your VET? Do you think that you can achieve these goals (selfefficacy)?

- Deliberate practice: Do you do other things besides your VET that contribute to your development in your professional field/craft (e.g., as a cook)? If yes, what do you do? Why do you do it? What is the underlying purpose?

That was the interview. Thanks a lot for your cooperation.

\section{Appendix 2}

\section{Two descriptions of students as portraits}

Rose (DS) was involved in goldsmithery training. Her task was to design a pillbox. In our study, she showed the most SRL behaviour (see Fig. 1).

The creative process of developing an idea preceded the observed lesson, but she explained that she first oriented herself to the task by making several drafts of her idea. Rose preferred a calm working place and chose to sit at a table with peers who were working seriously. To concentrate and protect herself from the busy surroundings, she worked with headsets and listened to music. She approached the task by following a certain order of steps (from coarse to fine finishing) and paid attention to her working time. During task execution, she kept an eye on her product (e.g., changes in the colour, straightness), and she paid close attention to her process by checking and testing the product regularly. She indicated that she wanted to perform well and prevent mistakes; therefore, she made adjustments to improve her performance (e.g., filing, polishing and starting over again). To evaluate her performance, Rose inspected her product and reflected on aspects that were still difficult for her and that she needed to improve. When she experienced problems, she first tried to solve them herself before consulting a peer or the teacher. Rose was willing to exert effort, and she engaged in practice activities to improve her skills during her leisure time. She worked on her own ideas in the evenings and had a variety of creative hobbies related to her professional field. She strived for perfection and took on challenges in her tasks. After graduation, she planned to travel around the world to develop her own style. In the future, she sought to open her own atelier, and she expressed self-confidence in achieving her aims ( 'Where there 
is a will, there is a way.'). During the observed lesson, she was calm, concentrated and persistent in her work.

Joey (KT) was involved in the automotive engineering training, and his task was to complete a thermostat and compression test. In our study, he showed the least SRL behaviour (see Fig. 1).

Joey indicated that he preferred a calm workplace, but he was less deliberate in structuring his environment according to his wishes. After a slow start and admonishing words from the teacher, he selected a task and oriented himself by looking up what needed to be done. Joey did not plan his steps, but decided what to do next on the spur of the moment. During task execution, he kept an eye on his product (e.g., the opened thermostat), but he forgot to switch off the hot plate at the end. To evaluate his performance, he checked whether anything was missing and awaited the teacher's assessment. Joey reflected on his behavioural issues and noted that he needed to pay attention to his working attitude. Joey was intrinsically and extrinsically motivated to engage in professional activities (e.g., fiddling with his scooter, repairing and checking cars for friends) and indicated that he did not give up easily. Joey's main goal was to gain a certificate and study further. He wanted to work as car mechanic specialising in gas and electric cars and to later start his own business and earn a lot of money. He thought he had the capacity to achieve his goals but indicated that he was not always willing to exert effort. During the observed lesson, he was rather talkative, but he finished his tasks on time.

\section{References}

Ainley, M., \& Patrick, L. (2006). Measuring self-regulated learning processes through tracking patterns of student interaction with achievement activities. Educational Psychological Review, 18, 267-286. https://doi.org/10.1007/s10648-006-9018-z.

Billett, S., Harteis, C., \& Gruber, H. (2018). Developing occupational expertise through everyday work activities and interactions. In K. A. Ericsson, N. R. R. Hoffman, A. Kozbelt, \& A. M. Williams (Eds.), The Cambridge handbook of expertise and expert performance (pp. 105-126) (2nd ed.). New York: Cambridge University Press.

Boekaerts, M., \& Cascallar, E. (2006). How far have we moved toward the integration of theory and practice in self-regulation? Educational Psychology Review, 18, 199-210. https://doi.org/10.1007/s10648-0069013-4.

Choi, S. J., Jeong, J. C., \& Kim, S. N. (2019). Impact of vocational education and training on adult skills and employment: An applied multilevel analysis. International Journal of Educational Development, 66, 129138.

Cedefop (2016). Leaving education early: putting vocational education and training centre stage. Volume I: investigating causes and extent. Luxembourg: Publications Office. Cedefop research paper; No 57. https://doi.org/10.2801/893397

De Bruijn, E., \& Leeman, Y. (2011). Authentic and self-directed learning in vocational education: Challenges to vocational educators. Teaching and Teacher Education, 27, 694-702. https://doi.org/10.1016/j. tate.2010.11.007.

De Bruijn, E., Billett, S., \& Onstenk, J. (2017). Vocational education in the Netherlands. In E. de Bruijn, S. Billett, \& J. Onstenk (Eds.), Enhancing teaching and learning in the Dutch vocational education system: Reforms enacted (pp. 3-36). Cham: Springer. https://doi.org/10.1007/978-3-319-50734-7_1.

Dignath, C., \& Büttner, G. (2008). Components of fostering self-regulated learning among students. A metaanalysis on intervention studies at primary and secondary school level. Metacognition \& Learning, 3, 231-264. https://doi.org/10.1007/s11409-008-9029-x. 
Dinsmore, D. L., Alexander, P. A., \& Loughlin, S. M. (2008). Focusing the conceptual lens on metacognition, self-regulation, and self-regulated learning. Educational Psychology Review, 20, 391-409. https://doi. org/10.1007/s10648-008-9083-6.

Eraut, M. (2004). Informal learning in the workplace. Studies in Continuing Education, 26, $247-274$. https://doi.org/10.1080/158037042000225245.

Ericsson, K. A. (2018). The differential influence of experience, practice, and deliberate practice on the development of superior individual performance of experts. In K. A. Ericsson, N. R. R. Hoffman, A. Kozbelt, \& A. M. Williams (Eds.), The Cambridge handbook of expertise and expert performance (pp. 745-769) (2nd ed.). New York: Cambridge University Press.

Ertmer, P. A., \& Newby, T. J. (1996). The expert learner: Strategic, self-regulated, and reflective. Instructional Science, 24, 1-24. https://doi.org/10.1037/0033-295X.100.3.363.

Harteis, C., Bauer, J., \& Gruber, H. (2008). The culture of learning from mistakes: How employees handle mistakes in everyday work. International Journal of Educational Research, 47, 223-231. https://doi. org/10.1016/j.ijer.2008.07.003.

Hattie, J. A., \& Timperley, H. (2007). The power of feedback. Review of Educational Research, 77, 81-112. https://doi.org/10.3102/003465430298487.

Järvenoja, H., Järvelä, S., \& Malmberg, J. (2015). Understanding regulated learning in situative and contextual frameworks. Educational Psychologist, 50, 204-219. https://doi.org/10.1080/00461520.2015.1075400.

Jossberger, H., Brand-Gruwel, S., Boshuizen, H. P. A., \& van de Wiel, M. (2010). The challenge of selfdirected and self-regulated learning in vocational education: A theoretical analysis and synthesis of requirements. Journal of Vocational Education and Training, 62, 415-440. https://doi.org/10.1080 $/ 13636820.2010 .523479$.

Jossberger, H., Brand-Gruwel, S., van de Wiel, M. W. J., \& Boshuizen, H. P. A. (2015). Teachers' perceptions of teaching in workplace simulations in vocational education. Vocations and Learning, 8, 287-318. https://oi.org/10.1007/s12186-015-9137-0.

Jossberger, H., Brand-Gruwel, S., van de Wiel, M. W. J., \& Boshuizen, H. P. A. (2018). Learning in workplace simulations in vocational education: A student perspective. Vocations \& Learning, 11, 179-204. https://doi.org/10.1007/s12186-017-9186-7.

Khaled, A., Gulikers, J., Biemans, H., \& Mulder, M. (2016). Occurrences and quality of teacher and student strategies for self-regulated learning in hands-on simulations. Studies in Continuing Education, 38, 101121. https://doi.org/10.1080/0158037X.2015.1040751.

Kicken, W., Brand-Gruwel, S., \& Van Merriënboer, J. J. G. (2008). Scaffolding advice on task selection: A safe path toward self-directed learning in on-demand education. Journal of Vocational Education and Training, 60, 223-239. https://doi.org/10.1080/13636820802305561.

Lindblom-Ylänne, S., Nevgi, A., \& Trigwell, K. (2011). Regulation of university teaching. Instructional Science, 39, 483-495. https://doi.org/10.1007/s11251-010-9141-6.

Littlejohn, A., Milligan, C., Fontana, R. P., \& Margaryan, A. (2016). Professional learning through everyday work: How finance professionals self-regulate their learning. Vocations \& Learning, 9, 2017-2226. https://doi.org/10.1007/s12186-015-9144-1.

Miles, M. B., \& Huberman, A. M. (1994). An expanded sourcebook: Qualitative data analysis (2nd ed.). Thousand Oaks: Sage.

Ministry of Education, Culture and Science (2017). Opnieuw minder jongeren voortijdig van school [Again less school dropout of teenagers] [News report, 21.2.2017]. Retrieved from https://www.rijksoverheid. nl/onderwerpen/vsv/nieuws/2017/02/21/opnieuw- minder-jongeren-voortijdig-van-school.

Müller, N. M., \& Seufert, T. (2018). Effects of self-regulation prompts in hypermedia learning on learning performance and self-efficacy. Learning \& Instruction, 58, 1-11. https://doi.org/10.1016/j. learninstruc.2018.04.011.

Nerland, M., \& Jensen, K. (2012). Epistemic practices and object relations in professional work. Journal of Education and Work, 25, 101-120. https://doi.org/10.1080/13639080.2012.644909.

Newman, R. S. (2002). How self-regulated learners cope with academic difficulty: The role of adaptive help seeking. Theory Into Practice, 41, 132-138. https://doi.org/10.1207/s15430421tip4102_10.

Panadero, E., Klug, J., \& Järvelä, S. (2016). Third wave of measurement in the self-regulated learning field: When measurement and intervention come hand in hand. Scandinavian Journal of Educational Research, 60, 723-735. https://doi.org/10.1080/00313831.2015.1066436.

Panadero, E., Jonsson, A., \& Botella, J. (2017). Effects of self-assessment on self-regulated learning and selfefficacy: For meta-analyses. Educational Research Review, 22, 74-98. https://doi.org/10.1016/j. edurev.2017.08.004. 
Persico, D., Milligan, C., \& Littlejohn, A. (2015). The interplay between self-regulated professional learning and teachers' work-practice. Procedia - Social and Beahvioral Sciences, 191, 2481-2486. https://doi. org/10.1016/j.sbspro.2015.04.590.

Pintrich, P. R. (1999). The role of motivation in promoting and sustaining self-regulated learning. International Journal of Educational Research, 31, 495-470. https://doi.org/10.1016/S0883-0355(99)00015-4.

Pintrich, P. R. (2003). A motivational science perspective on the role of student motivation in learning and teaching contexts. Journal of Educational Psychology, 95, 667-686. https://doi.org/10.1037/00220663.95.4.667.

Schunk, D. H. (2008). Metacognition, self-regulation, and self-regulated learning: Research recommendations. Educational Psychology Review, 20, 463-467. https://doi.org/10.1007/s10648-008-9086-3.

Schunk, D. H., Greene, J. A., \& J. A. (Eds.). (2018). Handbook of self-regulation of learning and performance. New York: Routledge.

Sitzmann, T., \& Ely, K. (2011). A meta-analysis of self-regulated learning in work-related training and educational attainment: What we know and where we need to go. Psychological Bulletin, 137, 421442. https://doi.org/10.1037/a0022777.

Slaats, A., \& Roosendaal, L. A. (1996). Manual of the inventory of learning styles for secondary vocational education. Tilburg: Tilburg University.

Slaats, A., Lodewijks, H. G. L. C., \& Van der Sanden, J. M. M. (1999). Learning styles in secondary vocational education: Disciplinary differences. Learning and Instruction, 9, 475-492. https://doi. org/10.1016/S0959-4752(99)00007-9.

Smit, K., de Brabander, C. J., Boekaerts, M., \& Martens, R. L. (2017). The self-regulation of motivation: Motivational strategies as mediator between motivational beliefs and engagement for learning. International Journal of Educational Research, 82, 124-134. https://doi.org/10.1016/j.ijer.2017.01.006.

Stevens, P. A. J., \& Vermeersch, H. (2010). Streaming in Flemish secondary schools: Exploring teachers' perceptions of and adaptations to students in different streams. Oxford Review of Education, 36, 267-284. https://doi.org/10.1080/03054981003629862.

Tynjälä, P. (2008). Perspectives into learning at the workplace. Educational Research Review, 3, 130-154. https://doi.org/10.1016/j.edurev.2007.12.001.

Van de Wiel, M. W. J., Van den Bossche, P., Janssen, S., \& Jossberger, H. (2011). Exploring deliberate practice in medicine: How do physicians learn in the workplace? Advances in Health Science Education, 16, 8195. https://doi.org/10.1007/s10459-010-9246-3.

Van Eekelen, I. M. (2005). Teachers' will and way to learn : Studies on how teachers learn and their willingness to do so. Maastricht: Universiteit Maastricht.

Van Grinsven, L., \& Tillema, H. (2006). Learning opportunities to support student self- regulation: Comparing different instructional formats. Educational Research, 48, 77-91. https://doi.org/10.1080 /00131880500498495.

Veenman, M. (2011). Alternative assessment of strategy use with self-report instruments: A discussion. Metacognition \& Learning, 6, 205-211. https://doi.org/10.1007/s11409-011-9080-x.

Veenman, M. V. J., Van Hout-Wolters, B. H. A. M., \& Afflerbach, P. (2006). Metacognition and learning: Conceptual and methodological considerations. Metacognition and Learning, 1, 3-14. https://doi. org/10.1007/s11409-006-6893-0.

Vermunt, J. D. H. M. (1996). Metacognitive, cognitive and affective aspects of learning styles and strategies: A phenomenographic analysis. Higher Education, 31, 25-50. https://doi.org/10.1007/BF00129106.

Winne, P. H. (2018). Cognition and metacognition within self-regulated learning. In D. H. Schunk \& J. A. Greene (Eds.), Handbook of self-regulation of learning and performance (pp. 36-48). New York: Routledge.

Wolters, C. A., \& Hussain, M. (2015). Investigating grit and its relations with college students' self-regulated learning and academic achievement. Metacognition \& Learning, 10, 293-311. Doi. https://doi. org/10.1007/s11409-014-9128-9.

Zimmerman, B. J. (2005). Attaining self-regulation. A social cognitive perspective. In M. Boekaerts, $P$. R. Pintrich, \& M. Zeidner (Eds.), Handbook of self-regulation (pp. 13-39) (2nd ed.). San Diego: Academic Press.

Zimmerman, B. J. (2006). Development and adaptation of expertise: The role of self- regulatory processes and beliefs. In K. A. Ericsson, N. Charness, P. J. Feltovich, \& R. R. Hoffman (Eds.), The Cambridge handbook of expertise and expert performance (pp. 683-703). New York: Cambridge University Press.

Zimmerman, B. J. (2013). From cognitive modelling to self-regulation: A social cognitive career path. Educational Psychologist, 48, 135-147. https://doi.org/10.1080/00461520.2013.794676.

Zimmerman, B. J., \& Bandura, A. (1994). Impact of self-regulatory influences on writing course attainment. American Educational Research Journal, 31, 845-862. https://doi.org/10.2307/1163397. 
Zimmerman, B. J., \& Martinez-Pons, M. (1986). Development of a structured interview for assessing student use of self-regulated learning strategies. American Educational Research Journal, 23, 614-628. https://doi.org/10.3102/00028312023004614.

Zimmerman, B. J., Bandura, A., \& Martinez-Pons, M. (1992). Self-motivation for academic attainment: The role of self-efficacy beliefs and personal goal setting. American Educational Research Journal, 29, 663676. https://doi.org/10.2307/1163261.

Publisher's Note Springer Nature remains neutral with regard to jurisdictional claims in published maps and institutional affiliations.

Helen Jossberger $\mathrm{PhD}$, is Assistant Professor at the Faculty of Human Sciences, Department of Educational Science. She teaches courses on learning and professional development, expertise research, instructional design, evaluation research, development and socialisation, and methodology. Her research focuses on selfdirected and self-regulated learning in vocational education, professional learning, workplace learning and (visual) expertise development. She received her Ph.D. at the Open Universiteit on self-regulated learning in vocational education. She obtained a Master degree in Cognitive Psychology at Maastricht University.

Saskia Brand-Gruwel $\mathrm{PhD}$, is member of the board of Zuyd University for Applied Sciences and professor in the Learning Sciences at the Open Universiteit. Her research focuses on instructional design for adaptive education to foster students' higher-order skills like information problem solving, self-directed and selfregulated learning in different domains (secondary education, vocational education and higher education). She organises and supervises $\mathrm{PhD}$ projects that study the above mentioned areas of interests.

Margje W. J. van de Wiel $\mathrm{PhD}$, is Assistant Professor at the Faculty of Psychology and Neuroscience at Maastricht University. She teaches courses on learning and human resources and is responsible for the staff development programme at her faculty. Her research focuses on professional learning, workplace learning, professional decision making, expertise development, and knowledge sharing. She received her Ph.D. at Maastricht University for her dissertation on medical expertise development. She obtained a Master degree in Cognitive Psychology at the Radboud University Nijmegen.

Henny P. A. Boshuizen $\mathrm{PhD}$, is Professor Emeritus of Education and Educational Sciences, Open Universiteit and visiting professor at the University of Turku. She is an expert in the domain of learning in the professions, knowledge transfer from education to practice, and pedagogical content knowledge. She organises and supervises $\mathrm{PhD}$ projects that study professional development in a variety of different domains (e.g. medicine; business administration; psychology; interdisciplinary learning).

\section{Affiliations}

\section{Helen Jossberger ${ }^{1} \cdot$ Saskia Brand-Gruwel ${ }^{2,3} \cdot$ Margje W. J. van de Wiel $^{4} \cdot$ Henny P. A. Boshuizen ${ }^{2,5}$}

1 Faculty of Human Sciences, Department of Educational Science, University of Regensburg, Universitätsstraße 31, 93053 Regensburg, Germany

2 Welten Institute, Open Universiteit, Heerlen, The Netherlands

3 Zuyd University for Applied Sciences, Heerlen, Netherlands

4 Faculty of Psychology and Neuroscience, Maastricht University, Maastricht, The Netherlands

5 Faculty of Education, University of Turku, Turku, Finland 